\title{
PENERAPAN MODEL PEMBELAJARAN JIGSAW UNTUK MENINGKATKAN PEMAHAMAN PENDIDIKAN AGAMA ISLAM SISWA KELAS IX SMPN 1 PRAMBON TAHUN PELAJARAN 2016/2017
}

\author{
Munir \\ Guru Agama Islam Sekolah Menengah Pertama Negeri(SMPN) Prambon \\ agamamunir@gmail.com
}

\begin{abstract}
Abstrak
Penerapan model pembelajaran "Jigsaw" diharapkan mampu membuat peserta didik menjadi antusias dalam mengikuti pembelajaran. Pada pembelajaran Jigsaw, pembelajaran difokuskan pada pemberian pengalaman belajar secara langsung (direct experience) dan menyenangkan. Masalah poko apakah melalui penerapan model pembelajaran jigsaw dapat meningkatkan pemahaman peserta didik pada mata pelajaran Pendidikan Agama Islam Materi Sombong kelas IX.1 di SMPN 1 Prambon tahun pelajaran 2016/ 2017?" Penelitian ini merupakan Penelitian Tindakan Kelas (PTK). Penelitian ini berbasis kolaboratif, sehingga dalam pelaksanaannya penelitian dilakukan melalui kerja sama dengan guru lain mata pelajaran Pendidikan Kewarganegaraan (PKn) kelas IX.1 di SMPN 1 Prambon. Peneliti berperan sebagai guru untuk melakukan tindakan pembelajaran sesuai perencanaan tindakan yang dibuat. Hasil penelitian ini menunjukkan, bahwa model pembelajaran jigsaw dapat meningkatkan pemahaman peserta didik dalam mata pelajaran Pendidikan Agama Islam materi pokok sombong di kelas IX.1 di SMPN 1 Prambon tahun pelajaran 2016/2017. Hal ini dapat dilihat dari peningkatan nilai peserta didik per siklus dimana pada pra siklus yang awal mulanya hanya $44,1 \%$ (15 peserta didik) dari 34 peserta didik yang mencapai nilai KKM 75. Sedangkan siklus I hanya mencapai 64,7\% (22 peserta didik) dari 34 peserta didik yang mencapai nilai KKM 75. Kemudian hasil tersebut diperbaiki lagi pada siklus II hingga mencapai ketuntasan belajar sebanyak 94,1\% ( 32 peserta didik) dari 34 peserta didik.

Sedangkan proses diskusi/nilai partisipasi observasi peserta didik di dalam kelas peserta didik juga mengalami peningkatan, dimana pada pra siklus masih mencapai $47,1 \%$ (16 peserta didik). Kemudian siklus I baru menggunakan model pembelajaran jigsaw yang ternyata masih mencapai $70,6 \%$ atau 24 peserta didik yang mencapai ketuntasan klasikal. Namun pada siklus II terdapat peningkatan yang sangat signifikan mencapai $97,05 \%$ atau 33 peserta didik berperan aktif dalam mengikuti proses pembelajaran mengunakan model pembelajaran jigsaw.
\end{abstract}

Kata Kunci: Model pembelajaran jigsaw, meningkatkan pemahaman agama siswa

\section{Latar Belakang}

Pembelajaran Pendidikan Agama Islam di sekolah menengah pertama, mengkaji tentang berbagai perilaku sifat terpuji maupun tercela seperti membahas tentang bab Sombong, Husnuzan, Qanaah, Tawakkal, dan lain-lain. Melalui mata pelajaran Pendidikan Agama Islam, peserta didik diarahkan untuk menjadi insan yang berperilaku baik, bertutur kata dengan sopan, dan memahami ilmu agama dengan baik dan benar. Dalam pembelajaran agama Islam di sekolah ini menggunakan berbagai metode dan pendekatan, dengan harapan siswa dengan mudah belajar dengan baik. Seperti pendapat Chalidah, bahwa proses belajar terjadi karena adanya interaksi antara peserta didik dengan lingkungannya. Oleh karena itu lingkungan perlu diatur sedemikian rupa sehingga timbul reaksi 
peserta didik ke arah perubahan tingkah laku yang diinginkan. ${ }^{1}$

Namun hal ini berbanding terbalik dengan fakta yang terjadi dilapangan. Berdasarkan studi pendahuluan yang telah dilakukan oleh peneliti di SMPN 1 Prambon kelas IX.1, proses belajar mengajar masih berpusat pada guru. Kegiatan pembelajan Pendidikan Agama Islam masih dilakukan secara konvensional, dengan guru lebih banyak menerangkan materi pembelajaran dan peserta didik hanya berperan sebagai penyimak. Pembelajaran Pendidikan Agama Islam yang demikian tidak atau belum memberi kesempatan maksimal kepada peserta didik untuk mengembangkan kreatiftasnya. Dimana proses pembelajaran yang berlangsung di kelas hanya diarahkan pada kemampuan peserta didik untuk menghafal informasi, peserta didik dipaksa untuk mengingat dan menimbun berbagai informasi tanpa dituntut untuk memahami informasi yang diperoleh untuk menghubungkanknya dengan situasi dalam kehidupan seharihari. Selain itu dalam proses belajar mengajar, guru hanya terpaku pada buku teks sebagai satu-satunya sumber pembelajaran.

Permasalahan yang kemudian muncul di lapangan sehubungan hal tersebut adalah peserta didik merasa kurang antusias selama mengikuti pembelajaran yang belangsung, ketika guru menerangkan banyak diantaranya yang tidak memperhatikan dan sibuk dengan kegiatan masing-masing seperti mengobrol, bercanda bahkan ada yang keluar masuk ruangan. Dengan model pembelajaran yang masih konvensional membuat peserta didik mengalami kesulitan dalam memahami materi yang disampaikan. Selain itu model pembelajaran yang digunakan oleh guru kurang memperhatikan karakteristik peserta didik dan mata pelajaran yang diajarkan sehingga membuat pembelajaran yang berlangsung kurang bermakna. Hal ini berdampak pada kurang terlatihnya keterampilan proses yang harusnya

1 Hasan Chalidah, Dimensi-Dimensi Psikologi Pendidikan Cet 1, (Surabaya: Al Ikhlas, 1994), 83. dikuasai oleh peserta didik dalam pembelajaran Pendidikan Agama Islam. Berdasarkan studi pendahuluan yang dilakukan oleh peneliti didapatkan hasil bahwa secara umum nilai rata-rata kelas hanya mencapai $44,1 \%$ dari nilai KKM (Kriteria Ketuntasan Minimum) yang telah ditentukan untuk mata pelajaran Pendidikan Agama Islam di sekolah tersebut yaitu 75. Dengan presentase ratarata $44,1 \%$ peserta didik di kelas IX.1 menguasai mata pelajaran Pendidikan Agama Islam, sedangkan 55,9 \% peserta didik kurang menguasai dan memahami mata pelajaran Pendidikan Agama Islam. Hal ini menunjukan bahwa sebagian besar peserta didik kurang berpedoman pada fakta-fakta diatas, salah satu alternatif pemecahan masalah yang dapat diambil adalah dengan penerapan model pembelajaran Jigsaw.

Berdasarkan latar belakang yang dipaparkan di atas, maka perlu diadakan penelitian tindakan kelas sebagai upaya perbaikan proses pembelajaran ${ }^{2}$ konsep dalam mata pelajaran Pendidikan Agama Islam, dengan melakukan penelitian tindakan kelas dengan judul: "Penerapan model pembelajaran jigsaw untuk meningkatkan pemahaman mata pelajaran pendidikan agama Islam siswa SMPN 1 Prambon Tahun Pelajaran 2016/2017”

Merujuk pada latar belakang yang telah dipaparkan, peneliti merumuskan masalah utama dalam penelitian ini yaitu "Apakah melalui penerapan model pembelajaran jigsaw dapat meningkatkan pemahaman peserta didik pada mata pelajaran Pendidikan Agama Islam Materi Sombong kelas IX.1 di SMPN 1 Prambon tahun pelajaran 2016/2017?"

\section{Kajian Pustaka \\ Hasil Belajar}

Untuk memperoleh pengertian yang obyektif tentang hasil belajar, perlu dirumuskan secara jelas, secara etimologi hasil belajar terdiri dari dua kata yaitu hasil dan belajar.Menurut kamus bahasa

2 A. Jauhar Fuad and Hamam, Teori Dan Praktik Penelitian Tindakan Kelas (PTK) (Tulungagung: STAIN Tulungagung, 2012). 
Indonesia, hasil adalah suatu yang ada (terjadi) oleh suatu kerja, berhasil sukses. Sementara menurut R. Gagne hasil dipandang sebagai kemampuan internal yang menjadi milik orang serta orang itu melakukan sesuatu.

Sedangkan belajar menurut Morgan, dalam buku Introduction to Psychology mengemukakan bahwa belajar adalah setiap perubahan yang relatif menetap dalam tingkah laku yang terjadi sebagai suatu hasil dan latihan atau pengalaman.

$$
\text { Menurut }
$$$$
\text { James }
$$

Whittaker, "Learning may be difined as the process by which behavior originates or is altered through training or experience". Bahwa belajar dapat didefinisikan sebagai proses dimana tingkah laku ditimbulkan atau diubah melalui latihan atau pengalaman. ${ }^{3}$

Sedangkan menurut Howard $L$. Kingsley "learning is the process by which behavior (in the broader sense) is originated or changed through practice or training".(Belajar adalah proses dimana tingkah laku (dalam arti luas) ditimbulkan atau diubah melalui praktek atau latihan). ${ }^{4}$

Dalam prespektif Islam tidak di jelaskan secara rinci dan operasional mengenai proses belajar (belajar), proses kerja sistem memori akal dan proses dikuasainya pengetahuan dan ketrampilan manusia. Namun Islam menekankan dalam signifikasi fungsi kognitif (akal) dan fungsi sensori (indera-indera) sebagai alat-alat penting untuk belajar sangat jelas. Sebagaimana firman Allah SWT dalam surat An-Nahl ayat 78:

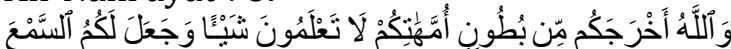

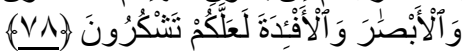

Artinya: "Dan Allah mengeluarkan kamu dari perut ibumu dalam keadaan tidak mengetahui sesuatupun, dan dia memberi kamu pendengaran, penglihatan dan hati, agar kamu bersyukur".

Dari ayat tersebut dapat diketahui bahwa ragam alat fisio-psikis dalam proses belajar yang terungkap dalam beberapa

3 Abu Ahmadi dan Widodo Supriyono, Psikologi Belajar, (Jakarta: Rineka Cipta, 2004), 126.

4 Abu Ahmadi dan Widodo Supriyono, Psikologi Belajar., 127. firman Allah SWT adalah sebgaai berikut :a) indera penglihat (mata), yakni alat fisik yang berguna untuk menerima informasi visual, b) indera pendengar (telinga) yakni alat fisik yang berguna untuk menerima informasi verbal, c) akal, yakni potensi kejiwaan manusia berupa sistem psikis yang kompleks untuk menyerap, mengolah, menyimpan dan memproduksi kembali item-item informasi dan pengetahuan, ranah kognitif.

Selain itu dalam beberapa ayat AlQur'an juga terdapat kata-kata kunci sepertiya'qilun, yatafakkarun, yubshirun, yasma'un dan sebagainya terdapat dalam Al-Qur'an merupakan bukti betapa pentingnya penggunaan fungsi ranah cipta dan karsa manusia dalam belajar dan meraih ilmu pengetahuan. Dari kata kunci tersebut Kegiatan belajar menurut Islam dapat berupa menyampaikan, menelaah, mencari, dan mengkaji, serta meniliti. ${ }^{5}$

$$
\text { Pendidikan Agama Islam }
$$

merupakan salah satu bidang studi yang wajib diajarkan di lembaga sekolah menengah pertama.Menurut Abdurrahman Saleh Abdullah, tujuan umum pendidikan agama Islam adalah membentuk kepribadian sebagai khalifah Allah atau sekurang-kurangnya mempersiapkan peserta didik ke jalan yang mengacu pada tujuan akhir manusia. Tujuan utama khalifah Allah adalah beriman kepada Allah dan tunduk patuh secara total kepada-Nya. Hal ini sesuai dengan firman Allah yang berbunyi :

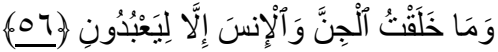

Artinya : Dan Aku tidak menciptakan jin dan manusia melainkan supaya mereka mengabdi kepada-Ku (Q.S. Adz-Dzariyat : 56).

Mata pelajaran ini dipandang sebagai salah satu mata pelajaran yang baik untuk menyebarkan, mengenalkan, menanamkan dan mendalami nilai-nilai religius, terutama mereka yang beragama Islam. Perilaku umat islam pada saat ini

5 Muhibbin Syah, Psikologi Pendekatan Suatu Pendekatan Baru, (Bandung: Remaja Rosdakarya, 1995), 99. 
merupakan hasil dari pembentukan perilaku yang bersumber dari pembelajaran Pendidikan Agama Islam. Karena didalam mata pelajaran Pendidikan Agama Islam terdapat beberapa muatan tentang aklak, yaitu tentang membiasakan berperilaku dengan sifat -sifat terpuji, membiasakan menghindari sifat-sifat tercela dan bagaimana cara bertatakarama yang baik. ${ }^{6}$

\section{Model Pembelajaran Jigsaw}

Model jigsaw nerupakan model belajar kooperatif dengan cara peserta didik belajar dalam kelompok kecil yang terdiri dari empat sampai dengan enam orang secara heterogen ${ }^{7}$. Peserta didik bekerja sama saling ketergantungan positif dan bertanggung jawab secara mandiri. Dalam model pembelajaran jigsaw, peserta didik memiliki banyak kesempatan untuk mengemukakan pendapat dan mengolah informasi yang didapat dan dapat meningkatkan ketrampilan berkomunikasi. Anggota kelompok bertanggung jawab atas keberhasilan kelompoknya dan ketuntasan bagian materi yang dipelajari dan dapat menyampaikan kepada kelompoknya.

Manfaat dari penggunaan model pembelajaran ini adalah jigsaw merupakan cara yang sangat efisien untuk mempelajari materi pelajaran. Proses jigsaw juga mendorong peserta didik untuk mendengarkan, terlibat aktif, dan berempati dengan memberikan kesempatan kepada setiap anggota kelompok sebagai bagian penting dalam kegiatan akademik. Anggota kelompok harus bekerja sama sebagai satu tim untuk mencapai tujuan bersama, setiap orang tergantung pada orang lain. Tidak ada peserta didik dapat berhasil sepenuhnya kecuali semua orang bekerja dengan baik bersama-sama sebagai sebuah tim. Jigsaw adalah bentuk kerjasama yang didesain untuk memfasilitasi interaksi antar semua peserta didik di kelas, membimbing mereka

6 Muhaimin, Arah baru pengembangan Pendidikan Islam (Bandung : Nuansa, 2003), 82.

7 Jauhar Fuad, "Strategi Pembelajaran Kooperatif (Studi Eksperimen)," Jurnal Pemikiran Keislaman 20, no. 1 (March 3, 2013), untuk menghargai satu sama lain sebagai kontributor untuk tugas bersama mereka.

\section{Langkah-langkah model pembelajaran Jigsaw}

Model pembelajaran kooperatif tipe jigsaw adalah sebuah model pembelajaran yang akan memeberikan beberapa keuntungan yaitu dapat mencegah dan mengurangi masalah konflik yang diakibatkan oleh adanya perbedaanperbedaan (suku/ras/agama) di antara para peserta didik, pembelajaran menjadi lebih baik, meningkatkan motivasi peserta didik, dan meningkatkan kenyamanan dalam proses pembelajaran.

Menurut Trianto langkah-langkah dalam pembelajaran kooperatif tipe jigsaw yaitu:

Peserta didik dibagi dalam beberapa kelompok (tiap kelompok terdiri dari 5-6 orang), a) Materi pelajaran diberikan kepada peserta didik dalam bentuk teks yang telah dibagi-bagi menjadi sub bab, b) Setiap anggota kelompok membaca sub bab yang ditugaskan dan bertanggungjawab untuk mempelajarinya. Tiap anggota kelompok ahli setelah kembali kekelompoknya bertugas mengajar temantemannya, c) anggota dari kelompok lain yang telah mempelajari sub bab yang sama bertemu dalam kelompok-kelompok ahli untuk mendiskusikan, d) pada pertemuan dan diskusi kelompok asal, peserta didik dikenai tagihan berupa kuis individu, e) anggota dari kelompok lain yang telah mempelajari subbab yang sama bertemu dalam kelompok-kelompok ahli untuk mendiskusikan. ${ }^{8}$

\section{Kajian Agama tentang Sombong}

Sombongk dari segi bahasa artinya besar kepala, secara istilah adalah merasa diri lebih (super) dari yang lain, seperti lebih kaya, lebih pandai, lebih tinggi jabatanya, lebih terhormat keturunannya dan lain sebagainya. Akobat orang yang

\footnotetext{
http://ejournal.iai-

tribakti.ac.id/index.php/tribakti/article/view/94

8 Aris Shoimin, 68 Model Pembelajaran

Innovatif dalam Kurikulum 2013, 91.
} 
sombong suka meremehkan orang lain. Sifat yang seperti ini akan menimbulkan berbagai macam sifat lain yang lebih buruk, seperti iri, dengki, hasud dan lain lain. Oleh karenanya orang yang memiliki sifat sombong tidak disukai di tengah-tengah masyarakat, karena menganggap dirinya serba lebih dibanding dengan lainnya. Dengaan demikian orang yang sombong besifat takabur dan tak dapat memberikan penilaian yang benar, bahkan menolak kebenaran, dengan kata lain buta terhadap kebenaran.

a. Macam-macam Sombong.

1) Sombong kepada Allah yaitu tidak memperdulikan agama Allah, tidak takut dengan ancaman Allah dan meremehkan syari'at Islam. Orang yang sombong pada Allah hampir setiap hari menggunakan waktunya untuk melakukan kegiatan-kegiatan yang menentang terhadap apa yang telah digariskan Allah dalam AlQur'an, seperti Mabuk-mabukan berjudi, berzina, mengundi nasib, bahkan menyekutukan Allah dengan yang lainnya.

2) Sombong kepada Rasul yaitu jauh dari taat kepada ajaran dan perilaku Rasulullah. Enggan dan merasa hina untuk mengikuti petunjuk Rasul, tidak sudi mengikuti Nabi Muhammad saw. Pada akhir zaman banyak sekali orang yang enggan dan ingkar terhadap sunnah Rasul, padahal sunnah Rasul merupakan dasar Islam yang kedua setelah AlQur'an. Sikap ingkar dengan sunah Rasul ini misalnya bangsa Yahudi beranggapan bahwa merekalah yang berhak menerima garis kenabian, sampai sekarangpun ada yang merasa hina bila melaksanakan perintah agama dan bahkan ada yang menganggap sudah usang dan ketinggalan zaman

3) Sombong terhadap sesama manusia yaitu menganggap lebih hebat, lebih mulia, lebih alim, lebih kaya, lebih kuat dan lain sebagainya. Ia menganggap remeh dan hina sewrta menganggap orang lain tidak berharga sama sekali dengan dibanding dirinya sendiri. Takabur terhadap orang yang belum seberapa ilmunya, ia kagum pada ilmu yang dimilikinya, seolah-olah tidak ada orang yang menyamainya, lebih-lebih melebihinya. Dan tidak sadaar bahwa manusia disamping memilliki kelebihan juga memiliki kekurangan. Sesungguhnya dia atas orang pandai ada yang lebih pandai

b. Akibat Negatif sifat sombong

Perilaku takabur hendanya ditinggalkan dan dijauhkan dari diri kita karena akan berakibat buruk, Adapun akibat perbuatan takabur diantaranya :

1) Merugikan diri sendiri dan orang lain

2) Dibenci Allah dan Rasul-Nya serta dibensi orang lain

3) Pada akhirnya akan masuk neraka jahannam untuk menghuni neraka selama-lamya.

c. Menjauhi sifat Takabur dalam kehidupan sehari-hari

Takabur adalah termasuk Akhlakul madzmumah (akhlak yang tercela) sebagai slah saatu penyakit ihati yang harus di jauhi. Menjauhi sifat takabur dalam kehidupan sehari-hari anta lain :

1) Menyembah pada Allah dengan tulus ikhlas sebagai tawadhu' kepada Allah

2) Mengikuti ajaran Rasul dengan sepenuh hati

3) Berkata yang sewajarnya saja tidak melebih-lebihkan kemampuan yang sebenarnya

4) Tidak merasa benar sendiri atau lebih sempurna sendiri dibanding orang lain

5) Tidak merendahklan harkat dan martabat orang lain

Contoh-contoh perilaku takabur diantara contoh perilaku takabur dalam kehidupan sehari-hari dapat dilihat dalam perilaku seperti :

1) Suka memuji diri sendiri

2) Suka meremehkan orang lain

3) Memalingkan muka bila bertemu dengan orang lain

4) Suka berlebih-lebihan dan berfoyafoya 
5) Suka perperilaku pamer dengan apa yang dimilikinya.

\section{Metode Penelitian \\ Desain Penelitian}

Penelitian ini merupakan Penelitian Tindakan Kelas (PTK). Penelitian ini berbasis kolaboratif, sehingga dalam pelaksanaannya penelitian dilakukan melalui kerja sama dengan guru lain mata pelajaran Pendidikan Kewarganegaraan (PKn) kelas IX.1 di SMPN 1 Prambon. Peneliti berperan sebagai guru untuk melakukan tindakan pembelajaran sesuai perencanaan tindakan yang dibuat.

Subjek penelitian ini adalah peserta didik kelas IX.1 di SMPN 1 Prambon Nganjuk yang berjumlah 34 peserta didik dengan perincian 8 putra dan 26 putri

\section{Teknik Pengumpulan Data}

Alat pengumpulan data dalam penelitian ini 1) bservasi. Observasi dilakukan untuk mengetahui aktivitas guru dan peserta didik saat pembelajaran sebagai langkah awal mengadakan penelitian. Lembar observasi juga digunakan untuk mengetahui bagaimana sikap afektif dan psikomotor peserta didik saat pembelajaran Pendidikan Agama Islam pada materi sombong berlangsung. 2) Tes. Tes sebagai alat penilaian adalah pertanyaan- pertanyaan yang diberikan kepada peserta didik untuk mendapat jawaban dari peserta didik dalam bentuk tes lisan, tulisan, atau perbuatan. Tes ini digunakan untuk mengetahui sejauh mana aspek kognitif anak sehingga dapat dijadikan tolak ukur penilaian pemahaman peserta didik. 3) Dokumentasin yaitu suatu teknik pengumpulan data dengan menghimpun dan menganalisis dokumen arsip, baik dokumen tertulis, gambar maupun elektronik. Dokumen sehubungan penelitian harus sesuai dengan fokus masalah penelitian dan tujuan.Dalam penelitian ini yang dipakai adalah dokumentasi dalam bentuk foto dan video selama pembelajaran berlangsung. ${ }^{9}$ Dokumentasi digunakan sebagai bahan

${ }_{9}^{9}$ Saur Tampubolon, Penelitian Tindakan Kelas, (Jakarta: PT Gelpra Aksara Pratama, 2013), 31. perbandingan pada saat refleksi untuk menilai kegiatan selama pembelajaran.

\section{Teknik Analisis Data}

Data Observasi Pengukuran skala penilaian pada proses pembelajaran, yaitu semakin tingginya nilai yang dihasilkan maka semakin baik kualitas proses pembelajaran, demikian juga sebaliknya semakin rendah nilai yang diperoleh maka semakin kurang kualitas proses pembelajaran tersebut. Data hasil observasi yang diperoleh digunakan untuk merefleksi tindakan yang telah dilakukan dan diolah secara deskriptif.

1. Untuk menilai ulangan atau tes formatif Peneliti melakukan penjumlahan nilai yang diperoleh peserta didik, yang selanjutnya dibagi dengan jumlah peserta didik yang ada di kelas tersebut sehingga diperoleh rata-rata tes formatif dapat dirumuskan: ${ }^{10}$

$\mathrm{X}$ bar $=\frac{\sum \mathrm{X}}{\sum \mathrm{N}}$

Keterangan :

$\mathrm{X}$ bar $=$ Nilai rata-rata

$\Sigma \mathrm{X}=$ Jumlah semua nilai peserta

didik

$\Sigma \mathrm{N}=$ Jumlah peserta didik

2. Untuk ketuntasan belajar, pada bidang studi Pendidikan Aama Islam kelas IX di SMPN 1 Prambon nilai KKM berdasarkan ketetapannya ataupun kesepakatannya ialah nilai 75 . Kemudian untuk menghitung persentase ketuntasan belajar digunakan rumus sebagai berikut: $P$ $=\frac{\Sigma \text { peserta didik yang tuntas belajar }}{\Sigma \text { peserta didik }} \times 100 \%$

\section{Prosedur Penelitian}

Model penelitian tindakan kelas yang digunakan dalam penelitian ini adalah model yang dikemukakan oleh Kemmis dan Mc Taggart. Penelitian tindakan dapat dipandang sebagai suatu siklus spiral dari penyusunan perencanaan, pelaksanaan tindakan, pengamatan (observasi), dan refleksi yang selanjutnya diikuti dengan siklus spiral berikutnya.

10 Saur Tampubolon, Penelitian Tindakan Kelas, (Jakarta: PT Gelpra Aksara Pratama, 2013), 35. 


\section{Hasil Penelitian}

Hasil penelitian tindakan kelas secara praktis dapat dijelaskan dalam narasi beikut ini:

\section{Pra Siklus}

Berdasarkan nilai post test pra siklus, ketuntasan belajar dari materi sombong dengan KKM 75 hanya 15 peserta didik $(44,1 \%)$, sedangkan peserta didik yang tidak tuntas nilainya sebanyak 19 peserta didik (55,9\%). Sedangkan nilai partisipasi observasi peserta didik di dalam kelas juga masih kurang yaitu hanya 16 peserta didik $(47,1 \%)$ Maka, ini menunjukkan guru perlu mencoba melakukan pembelajaran dengan menggunakan metode yang lain.

\section{Siklus 1}

Berdasarkan hasil pra siklus peneliti mengadakan tindakan kelas yang tujuannya adalah meningkatkan hasil belajar peserta didik kelas IX.1 di SMPN 1 Prambon. Pada siklus I ini, peneliti menggunakan metode jigsaw pada mata pelajaran Pendidikan Agama Islam materi sombong dan penelitian tindakan kelas siklus I dilaksanakan pada tanggal 17 Januari 2017 dengan melakukan tahapan sebagai berikut

\section{a. Perencanaan}

Pada tahapan perencanaan, ada beberapa hal yang dipersiapkan oleh peneliti, yaitu :

1) Membuat desain Rencana Pelaksanaan Pembelajaran dengan penerapan model pembelajaran Jigsaw (terlampir)

2) Menyediakan alat peraga yang dibutuhkan untuk membantu menyampaikan materi.

3) Menyusun soal - soal tes yang akan digunakan untuk mengukur kemampuan peserta didik dalam menguasai materi pembelajaran (terlampir).

4) Membuat pedoman observasi beserta panduan peneliannya (terlampir).

5) Pendokumentasian (terlampir)

b. Tindakan

Tindakan siklus I dilaksankan pada hari Selasa tanggal 17 Januari 2017 pukul 09.55 WIB sampai dengan 11.15 WIB dan dilaksanakan melalui pengajaran langsung di kelas berdasarkan RPP yang sudah disusun.

Tindakan kelas dimulai dengan berdoa, mengecek kesiapan belajar peserta didik, apersepsi dan menyampaikan tujuan-tujuan yang hendak dicapai dalam pembelajaran serta memberikan motivasi. Apersepsi dilakukan dengan memberikan pertanyaan yang sesuai dengan kehidupan sehari-hari. Dilanjutkan dengan memberikan motivasi pentingnya mempelajari materi sombong dan mengkaitkan materi pelajaran dengan kehidupan sehari - hari di lingkungan sekitar.

Kegiatan inti pada tindakan kelas siklus I dilakukan dengan prosedur sebagai berikut :

1) Membagi peserta didik menjadi 4 kelompok dengan anggota sekitar 8 - 9.

2) Setiap kelompok mendapat Lembar Kerja Kelompok sesuai dengan tugas yang akan dilakukan oleh tiap - tiap kelompok.

3) Setiap kelompok akan melakukan kegiatan diskusi dengan mendengarkan penjelasan dari anggota kelompok lain yang berkunjung. Guru memandu dan mengamati jalannya diskusi serta memberikan umpan balik mengenai kegiatan yang dilakukan yang dilakukan.

4) Setelah semua utusan dari semua kelompok selesai melaksanakan tugasnya maka tiap kelompok melakukan diskusi untuk membahas materi yang telah diberikan oleh utusan kelompok lain.

5) Melakukan diskusi antar kelompok dimana guru bertindak sebagai moderator.

Di akhir tindakan siklus I, peserta didik dibimbing dan diarahkan untuk menyimpulkan materi tentang sombong. Selanjutnya menyampaikan pesan pesan moral di akhir kegiatan belajar.

Data yang berhasil dikumpulkan untuk mengetahui peningkatan hasil belajar peserta didik diperoleh dari hasil post test yang diberikan kepada peserta didik pada setiap siklusnya. Untuk menghitung perolehan hasil belajar peserta didik terhadap materi syirik digunakan rumus 
ketuntasan belajar individu, lalu dicari nilai rata - ratanya untuk kemudian mengukur ketuntasan belajar peserta didik dengan menggunakan ketuntasan belajar klasikal. Melalui tabel berikut dapat diperoleh gambaran hasil belajar peserta didik kelas IX.1 SMPN 1 Prambon, sebagai berikut:

Berdasarkan nilai di atas, ketuntasan belajar dari materi sombong dengan KKM 75 hanya 22 peserta didik $(64,7 \%)$, sedangkan peserta didik yang tidak tuntas nilainya sebanyak 12 peserta didik $(35,3 \%)$. Sedangkan nilai partisipasi observasi peserta didik di dalam kelas yang tuntas/lulus ialah masih 24 peserta didik $(70,6 \%)$. Hal ini menunjukkan peneliti perlu mencoba melakukan siklus II dengan menggunakan metode yang sama.

\section{c. Observasi}

Observasi dilakukan dengan menggunakan lembar observasi. Proses observasi dilakukan oleh guru kolaborator untuk mengamati aktivitas peserta didik dalam kelas selama proses belajar mengajar dengan menerapkan model pembelajaran jigsaw. Pengamatan juga dilakukan terhadap partisipasi peserta didik di dalam kelas selama proses pembelajaran berlangsung dan dampak yang ditimbulkan dari perilaku peserta didik selama proses pembelajaran. Dari pengamatan dengan guru kolaborator didapatkan hasil sebagai berikut :

\section{d. Refleksi}

Berdasarkan hasil observasi dan tes yang telah dilakukan, maka peneliti bersama observer melakukan diskusi untuk membahas data yang telah diperoleh tersebut. Setelah dianalisis, maka ditemukan fakta bahwa antara data yang diperoleh dengan desain pemelajaran yang telah direncanakan serta indikator keberhasilan penelitian yang telah ditetapkan terdapat beberapa ketidak sesuaian, yaitu sebagai berikut :

1) Peneliti yang bertindak sebagai pengajar belum maksimal dalam mengarahkan dan membimbing peserta didik dalam melakukan percobaan. Akibatnya ada beberapa kelompok yang mengalami kesulitan dalam melakukan diskusi.
2) Masih banyak peserta didik yang tidak aktif dalam melakukan diskusi antar peserta didik dalam kelompok. Hal ini disebabkan karena guru dalam menjelaskan langkah - langkah kegiatan dimana masih ada peserta didik yang asyik dengan lembar kerja yang dibagikan terlebih dahulu.

3) Pelaksanaan diskusi antar kelompok untuk membahas ringkasan materi belum berjalan optimal.

4) Aktivitas belajar peserta didik belum mencapai indikator keberhasilan, dimana hanya terdapat $64,7 \%$ dari 34 anak yang telah mencapai nilai KKM.

Dengan demikian masih diperlukan adanya siklus II agar dapat memperoleh hasil yang lebih baik. Adapun perbaikan perbaikan tersebut adalah sebagai berikut :

a) Membagi peserta didik dalam beberapa kelompok yang heterogen dengan meminta saran dari wali kelas IX.1 sehingga peserta didik yang memiliki tingkat kognitif yang tinggi mampu menjadi tutor teman sebaya dalam kelompoknya. Hal inilah yang mampu memungkinkan kegiatan percobaan akan berlangsung optimal.

b) Mengkondisikan kelas terlebih dahulu agar dalam proses pembelajaran dapat berjalan dengan tenang dan kondusif

c) Lebih memaksimalkan dalam mengarahkan dan membimbing serta mengontrol keaktifan peserta didik dalam melakukan percobaan, sehingga mereka bisa mencapai tujuan yang dikehendaki dalam percobaan.

d) Memberikan penekanan pada setiap kelompok untuk melakkan diskusi antar peserta didik dalam kelompok agar membahas hasil percobaan pada kelompoknya masing - masing.

\section{Siklus 2}

\section{a. Perencanaan}

Pada siklus 2 ini tahapan perencanaan masih sama dengan siklus 1 ada beberapa hal yang dipersiapkan oleh peneliti, yaitu : 
1) Membuat desain Rencana Pelaksanaan Pembelajaran dengan penerapan model pembelajaran jigsaw (terlampir)

2) Menyusun soal - soal tes yang akan digunakan untuk mengukur kemampuan peserta didik dalam menguasai materi pembelajaran (terkampir)

3) Membuat pedoman observasi beserta panduan peneliannya (terlampir)

4) Pendokumentasian (terlampir)

\section{b. Tindakan}

Tindakan sklus II dilaksanakan pada hari Selasa tanggal 24 Januari 2017 pada pukul 09.55 WIB - 11.15 WIB dengan mengadakan pengajaran langsung di kelas.

1) Tindakan kelas dimulai dengan berdoa, mengecek kesiapan belajar peserta didik, apersepsi dan menyampaikan tujuan - tujuan yang hendak dicapai dalam pembelajaran serta memberikan motivasi. Apersepsi dilakukan dengan memberikan pertanyaan yang sesuai dengan kehidupan sehari - hari. Dilanjutkan dengan memberikan motivasi pentingnya mempelajari materi syirik dan mengkaitkan materi pelajaran tersebut dengan kehidupan sehari - hari di lingkungan sekitar.

Kegiatan inti pada tindakan kelas siklus II dilakukan dengan prosedur sebagai berikut :

a) Membagi peserta didik menjadi 4 kelompok dengan anggota sekitar $9-10$.

b) Setiap kelompok mendapat Lembar Kerja Kelompok sesuai dengan tugas yang akan dilakukan oleh tiap - tiap kelompok.

c) Setiap kelompok akan melakukan kegiatan diskusi dengan mendengarkan penjelasan dari anggota kelompok lain yang berkunjung. Guru memandu dan mengamati jalannya diskusi serta memberikan umpan balik mengenai kegiatan yang dilakukan yang dilakukan.

d) Setelah semua utusan dari semua kelompok selesai melaksanakan tugasnya maka tiap kelompok melakukan diskusi untuk membahas materi yang telah diberikan oleh utusan kelompok lain. e) Melakukan diskusi antar kelompok dimana guru bertindak sebagai moderator.

Di akhir tindakan sikus II, peserta didik dibimbing dan diarahkan untuk menyimpulkan materi pentingnya materi sombong. Selanjutnya peneliti menyampaikan pesan - pesan moral di akhir kegiatan belajar.

Data yang berhasil dikumpulkan untuk mengetahui peningkatan hasil belajar peserta didik diperoleh dari hasil post test yang diberikan kepada peserta didik pada setiap siklusnya. Untuk menghitung perolehan hasil belajar peserta didik terhadap materi sombong digunakan rumus ketuntasan belajar individu, lalu dicari nilai rata - ratanya untuk kemudian mengukur ketuntasan belajar peserta didik dengan menggunakan ketuntasan belajar klasikal. Melalui tabel berikut dapat diperoleh gambaran hasil belajar peserta didik kelas IX.1 SMPN 1 Prambon, sebagai berikut:

Berdasarkan nilai di atas, ketuntasan belajar dari materi sombong dengan KKM 75 mencapai 32 peserta didik $(94,1 \%)$, sedangkan peserta didik yang tidak tuntas nilainya sebanyak 2 peserta didik $(6,8 \%)$. Sedangkan nilai partisipasi observasi peserta didik di dalam kelas juga mengalami kenaikan yaitu yang tuntas/lulus ada 33 peserta didik (97,05\%). Hal ini menunjukkan bahwa pada siklus II mengalami kenaikan hasil belajar peserta didik sebesar $29 \%$.

\section{c. Observasi}

Observasi dilakukan dengan menggunakan lembar observasi. Proses observasi dilakukan oleh guru kolaborator untuk mengamati partisipasi peserta didik di kelas selama proses belajar mengajar dengan menerapkan model pembelajaran jigsaw selama proses pembelajaran berlangsung dan dampak yang ditimbulkan dari perilaku peserta didik selama proses pembelajaran. Dari pengamatan dengan guru kolaborator didapatkan hasil sebagai berikut :

\section{d. Refleksi}

Berdasarkan grafik hasil penelitian siklus II menunjukkan bahwa peneliti sudah dapat memberikan motivasi pada peserta 
didik. Peneliti dapat menerangkan materi dengan model pembelajaran jigsaw pada peserta didik, peneliti juga sudah dapat mengelola kelas dengan baik dan peneliti sudah dapat membuat setting kelas dengan cukup baik juga.

Demikian pula dengan hasil belajar siswa yang sudah dapat mencapai indikator keberhasilan penelitian dengan KKM 75 sebanyak 94,1 \% karena sebanyak 32 peserta didik telah mampu mencapai ketuntasan nilai minimum. Sedangkan untuk partisipasi observasi peserta didik di dalam kelas mencapai 97,05\%. Hal ini berarti tindakan kelas pada siklus II sudah berhasil sehingga tidak diperlukan lagi siklus III sebagai perbaikan.

Penelitian Tindakan Kelas ini dilakukan pada tanggal 10 Januari sampai 24 Januari 2017 dan dilakukan dalam 2 siklus. Tahap pra siklus dilakukan dengan menganalisa data yang dimiliki oleh guru kelas sehingga didapatkan kesimpulan perlu adanya tindakan kelas karena hasil pra siklus menunjukkan bahwa nilai yang diraih oleh peserta didik belum mencapai nilai ketuntasan yang telah ditentukan pihak sekolah.

Siklus I dilaksanakan tanggal 17 Januari 2017 menggunakan metode jigsaw pada materi Sombong sedangkan siklus II dilaksanakan pada tanggal 24 Januari 2016 dengan metode yang sama tapi dengan materi yang berbeda.

Berdasarkan paparan data dan analisis data per siklus mulai dari pra siklus, siklus I dan siklus II, sebagai perbandingan dapat peneliti gambarkan sebagai berikut :

Nilai peserta didik meningkat tiap siklusnya dimana pada pra siklus yang menggunakan metode diskusi ketuntasan hanya 15 siswa atau sebesar $44,1 \%$ dengan rata - rata kelas 62,7. Setelah melakukan model pembelajaran jigsaw pada siklus I menjadi 22 peserta didik atau sebesar 64,7 $\%$ dengan rata-rata 73 dan diperbaiki lagi pada siklus II sehingga ketuntasan belajar siswa mencapai $94,1 \%$ atau 32 peserta didik dengan nilai rata-rata mencapai 93,3.

Setelah melihat dan menganalisis data di atas, dapat diambil hasil akhir berupa apa yang yang telah dilakukan oleh peneliti dalam menyampaikan materi sombong pada mata pelajaran Pendidikan Agama Islam dengan menggunakan model pembelajaran jigsaw ternyata mampu meningkatkan hasil pemahaman peserta didik kelas IX.1 di SMPN 1 Prambon. Hipotesis menyatakan bahwa dengan menggunakan model pembelajaran jigsaw pemahaman peserta didik kelas IX.1 di SMPN 1 Prambon meningkat.

Hasil penelitian di atas sesuai dengan teori yang menyatakan bahwa model jigsaw nerupakan model belajar kooperatif dengan cara peserta didik belajar dalam kelompok kecil yang terdiri dari empat sampai dengan enam orang secara heterogen. Peserta didik bekerja sama saling ketergantungan positif dan bertanggung jawab secara mandiri. Dalam model pembelajaran jigsaw, peserta didik memiliki banyak kesempatan untuk mengemukakan pendapat dan mengolah informasi yang didapat dan dapat meningkatkan ketrampilan berkomunikasi. Hal ini terjadi karena ada tekanan bahwa anggota kelompok bertanggung jawab atas keberhasilan kelompoknya dan ketuntasan bagian materi yang dipelajari dan dapat menyampaikan kepada kelompoknya.

Selain itu manfaat dari penggunaan model pembelajaran ini adalah merupakan cara yang sangat efisien untuk mempelajari materi pelajaran. Proses jigsaw juga mendorong peserta didik untuk mendengarkan, terlibat aktif, dan berempati dengan memberikan kesempatan kepada setiap anggota kelompok sebagai bagian penting dalam kegiatan akademik. Anggota kelompok harus bekerja sama sebagai satu tim untuk mencapai tujuan bersama, setiap orang tergantung pada orang lain. Tidak ada peserta didik dapat berhasil sepenuhnya kecuali semua orang bekerja dengan baik bersama-sama sebagai sebuah tim. Jigsaw adalah bentuk kerjasama yang didesain untuk memfasilitasi interaksi antar semua peserta didik di kelas, membimbing mereka untuk menghargai satu sama lain sebagai kontributor untuk tugas bersama mereka. Model pembelajaran jigsaw ini untuk meningkatkan rasa tanggung jawa siswa 
terhadap pembelajaran yang dilakukan sendiri dan juga untuk pembelajaran orang lain. Siswas di sini tidak hanya mempelajari materi yang diberikan, tetapi mereka juga harus siap memberikan dan mengajarkan materi tersebut pada anggota kelompoknya. Dengan demikian siswa saling tergantung satu dengan yang lain dan harus bekerja sama secara kooperatif untuk mempelajari materi yang diberikan. Para anggota dari tim-tim yang berbeda dengan topik yang sama bertemu untuk diskusi (ahli tim), saling membantu satu sama yang lain tentang topik pembelajaran yag ditugaskan kepada mereka.

Pada model pembelajaran kooperatif tipe Jigsaw, terdapat kelompok asal dan kelompok ahli, hal ini sangat membantu kepada anggota lain. Kelompok asal yaitu kelompok induk siswa yang beranggotakan siswa dengan kemampuan, asal, dan latar belakang keluarga yang beragam. Kelompok asal merupakan gabungan dari beberapa ahli. Kelompok ahli yaitu kelompok siswa yang terdiri dari anggota kelompok asal yang berbeda yang ditugaskan untuk mempelajari dan mendalami topik tertentu dan menyelesaikan tugas-tugas yang berhubungan dengan topiknya untuk kemudian dijelaskan kepada anggota kelompok asal.

\section{Kesimpulan}

Keberhasilan proses belajar mengajar ditentukan oleh beberapa aspek yang mendukungnya. Aspek - aspek tersebut antara lain penggunaan metode pembelajaran yang tepat, sumber ajar yang sesuai, pemilihan dan penggunaan media yang tepat, situasi dan kondisi kelas serta kondisi guru dan peserta didik yang kondusif.

Berdasarkan hasil penelitian yang telah dilakukan oleh peneliti dapat diambil kesimpulan sebagai berikut :

Model pembelajaran jigsaw dapat meningkatkan pemahaman peserta didik dalam mata pelajaran Pendidikan Agama Islam materi pokok sombong di kelas IX.1 di SMPN 1 Prambon tahun pelajaran 2016/2017. Hal ini dapat dilihat dari peningkatan nilai peserta didik per siklus dimana pada pra siklus yang awal mulanya hanya $44,1 \%$ (15 peserta didik) dari 34 peserta didik yang mencapai nilai KKM 75 . Sedangkan siklus I hanya mencapai $64,7 \%$ (22 peserta didik) dari 34 peserta didik yang mencapai nilai KKM 75. Kemudian hasil tersebut diperbaiki lagi pada siklus II hingga mencapai ketuntasan belajar sebanyak 94,1\% ( 32 peserta didik) dari 34 peserta didik.

Sedangkan proses diskusi/nilai partisipasi observasi peserta didik di dalam kelas peserta didik juga mengalami peningkatan, dimana pada pra siklus masih mencapai $47,1 \%$ (16 peserta didik). Kemudian siklus I baru menggunakan model pembelajaran jigsaw yang ternyata masih mencapai $70,6 \%$ atau 24 peserta didik yang mencapai ketuntasan klasikal. Namun pada siklus II terdapat peningkatan yang sangat signifikan mencapai $97,05 \%$ atau 33 peserta didik berperan aktif dalam mengikuti proses pembelajaran mengunakan model pembelajaran jigsaw.

\section{Saran}

Ada bebarapa saran yang ingin peneliti sampaikan sehubungan dengan penelitian yang telah peneliti lakukan di kelas IX.1 di SMPN 1 Prambon dengan menggunakan model pembelajaran jigsaw, antara lain :

1. Bagi peserta didik yang peneliti banggakan, semoga dengan hasil yang telah diraih, dapat memacu kreativitas dan semangat belajar para peserta didik, sehingga dapat mencapai hasil yang diinginkan dan tidak terjadi lagi mendapatkan nilai yang tidak diinginkan.

2. Bagi praktisi pendidkan atau guru yang tertarik untuk menerapkan model pembelajaran jigsaw, perlu mempersiapkan hal - hal yang dibutuhkan agar ketika akan dilaksanakan tidak mengalami hambatan sehingga malah menjadikan model pembelajaran ini menjadi tidak berguna. Karena harus dipahami bahwa model ini diterapkan untuk menjembatani karateristik peserta 
didik kita yang berbeda - beda agar tujuan pembelajaran yang diinginkan dapat tercapai dengan maksimal. Namun apapun model pembelajaran yang dipergunakan, pahamilah terlebih dahulu karakter peserta didik yanng dihadapai agar nanti dalam mempergunakan metode pembelajaran dapat memberikan hasil sesuai yang diinginkan serta harus selalu menjadi guru yang kreatif agar anak didik kita dapat memperoleh hasil yang maksimal.

3. Bagi peneliti yang hendak menggunakan model pembelajarn ini sebagai bahan penelitian untuk pelajaran apapun, diharapkan untuk melakukan pemahaman terlebih dahulu tentang model pembelajaran ini. Kesesuaian materi sangat diperhatikan agar penerapan model pembelajaran jigsaw ini dapat memperoleh hasil yang maksimal sesuai yang diharapkan.

\section{Daftar Pustaka}

Arikunto, Suharsimi. 2010, Penelitian Tindakan Kelas. Jakarta: Bumi Aksara, 2008.

Arikunto, Suharsimi. Prosedur Penelitian Suatu Pendekatan Praktek. Jakarta: Penerbit Rineka Cipta

Ahmadi, Abu dan Widodo Supriyono. 1994, Psikologi Belajar. Jakarta: Rineka Cipta, 2004.

Chalidjah, Hasan. 2005, Dimensi-Dimensi Psikologi Pendidikan Cet 1, Surabaya: Al Ikhlas,

Fuad, Jauhar, "Strategi Pembelajaran Kooperatif (Studi Eksperimen)," Jurnal Pemikiran Keislaman 20, no. 1 (March 3, 2013), http://ejournal.iaitribakti.ac.id/index.php/tribakti/ar ticle/view/94.

Fuad, A. Jauhar, and Hamam, Teori Dan Praktik Penelitian Tindakan Kelas (PTK) (Tulungagung: STAIN Tulungagung, 2012)

Hamalik, Oemar. 2009, Proses Belajar Mengajar. Jakarta, PT Bumi Aksara.
Muhaimin. , 2003 Arah baru pengembangan Pendidikan Islam. Bandung: Nuansa.

Muhammad Zainal Abidin, Akidah Akhlak, http://meetabied.wordpress.com 2009/10/30 /aqidah-akhlak/, diakses tanggal 19 Januari 2017.

Syarifudin, Tatang. Landasan Pendidikan. Jakarta: Direktorat Jenderal Pendidikan

Syah, Muhibbin. 1995, Psikologi Pendekatan Suatu Pendekatan Baru. Bandung: Remaja Rosdakarya

Sudjana, Nana. 1995, Penilaian Hasil Proses Belajar Mengajar. Bandung: PT. Remaja Rosdakarya.

Sudjana, Nana. 2010, Evaluasi Proses dan Hasil Pembelajaran. Jakarta: Bumi Aksara.

Shoimin, Aris. 68 Model Pembelajaran Innovatif dalam Kurikulum 2013.Yoyakarta: Ar - Ruzz, t.t.

Sutopo, H.B. Metodologi Penelitian Kualitatif: Tinjauan Teoritis dan Praktis. Malang: Lembaga Penelitian Universitas Islam Malang, t.t.

Ika setiani, Dica Lanita Affinoxy, Ismunajab, 2010, Pendidikan Agama Islam untuk SMP kelas IX: Swadaya Murni.

Tim MGMP PAI Kab. Nganjuk, Buku Kerja Siswa Pendidikan Agama Islam untuk SMP kelas IX, 2016

Tampubolon, Saur. 2013, Penelitian Tindakan Kelas. Jakarta: PT Gelpra Aksara Pratama. 